\title{
OLD RHETORIC AND NEW DEVICES: QUARANTINE SHIPS AS AN INSTRUMENT OF EXTERNALIZATION
}

\author{
Stefania SPADA'
}

COBISS 1.01

\section{ABSTRACT \\ Old Rhetoric and New Devices: Quarantine Ships as an Instrument of Externalization}

The article aims to illustrate and explore the rhetoric and institutional approach toward migrants - asylum seekers in particular - undertaken by Italy following the COVID-19 crisis. Through the account of the different "narrative phases" and the consequent institutional action undertaken, this article intends to demonstrate how the health crisis has sharpened and even intensified pre-existing attitudes and practices. The actions taken in the last year can be understood as a further step in the process of externalizing the borders. Through the instrumental use of rhetoric and illegitimate practices, a sort of de-territorialization has been implemented through the use of quarantine ships.

KEYWORDS: asylum seekers, COVID-19, quarantine ships, rhetoric, externalization

\section{IZVLEČEK}

\section{Stara retorika in nova sredstva: Karantenske ladje kot sredstvo eksternalizacije} Članek ilustrira in analizira verbalni in institucionalni pristop Italije do migrantov, še zlasti prosilcev za azil, med pandemijo covida-19. Z opisi različnih »vsebinskih faz« in posledičnih institucionalnih dejavnosti prikazuje, kako je zdravstvena kriza zaostrila in celo okrepila že obstoječe pristope in prakse. Aktivnosti prejšnjega leta lahko razumemo kot nadaljnji korak v procesu eksternalizacije meja. Država je z instrumentalizacijo verbalnih in nezakonitih praks izvedla nekakšno deteritorializacijo, ki temelji na uporabi karantenskih ladij.

KLJUČNE BESEDE: prosilci za azil, covid-19, karantenske ladje, retorika, eksternalizacija

$\mathrm{PhD}$ in law with double disciplinary recognition, $\mathrm{BA}$ and specialization in anthropology; research fellow, Department of Legal Sciences CIRSFID (Centro di Ricerca in Storia del Diritto, Filosofia e Sociologia del Diritto e Informatica Giuridica), Via Galliera 3, 40121 Bologna, Italy; s.spada@unibo.it, https://orcid.org/0000-0003-1128-868X. 


\section{BETWEEN FACTS AND RHETORIC, OR READY-MADE SCAPEGOATS'}

\section{Phase 0}

In late January and early February 2020, official communication about the 2019 novel coronavirus was guided by underestimating what later became a global health emergency. This behavior was a typical example of Salgari syndrome, ${ }^{2}$ a rhetorical device that frames infectious diseases as exotic imports. So, it was the case that the virus had struck China and institutional narratives presented it as a problem exclusively limited to that territory - and to those living within its boundaries (as if a virus ever took notice of a passport). On January 30, 2020, the first official communication on this matter issued by Italian prime minister Conte and health minister Speranza acknowledged the first two cases of coronavirus, a couple of Chinese tourists who were put into confinement as a result. On that occasion, the government reassured that all flights to and from China had been suspended, ${ }^{3}$ a preventative action that reinforced the notion of a Chinese affaire, something purely circumscribed to that region of the world. Such declarations were accompanied by promising words regarding the future so as not to cause unnecessary alarm. Apart from the issues deriving from this type of misinformation which directly impacted the quicker spread of the virus, it is worth remembering how this way of framing had severe and lasting effects on a pragmatic level, too. Some Chinese people - or at least people who "looked" Chinese - became victims of targeted attacks that often ended up in fullyfledged lynching, and a few business locations were vandalized in the process. The imaginary construct of a Chinese "spreader of the plague" - unctor - was entirely shattered on February 21, 2020, when news broke out that the "patient zero" was an Italian citizen from Codogno. And yet, one year on, the concept of a Chinese disease remains part of the popular discourse.

\section{Phase 1}

In the weeks that followed, broadcast news solely focused on the seemingly uncontrollable spread of the disease, quickly forgetting what had happened during

1 The reflections presented in this article derive from long-term ethnographic research aimed at understanding how imaginaries, stereotypes, and prejudice lead to exclusionary differential treatment for migrants. The analysis was based on a daily ethnography of institutional narratives, media communication, and how they are perceived by common discourse and circulated through social media. The analysis also included documents and dossiers published in recent months on the specific phenomenon.

2 According to this assumption, the migrant person is said to be a carrier of rare and exotic diseases, especially infectious ones, although the data collected never supported this belief; see Geraci (2006). https://www.youtube.com/watch?v=tKiwp1u780g (26 Dec. 2020). 
January and February - including the anti-Chinese national psychosis. Both institutional and media narratives concentrated on the rising numbers of deaths and contagion and the collapse of the health services, culminating in the lockdown declaration of March 11, 2020. The continuous migration flows into the country, usually at the forefront of every media outlet, suddenly became invisible to the population. From the Salgari syndrome in anti-Chinese Phase 0, there was a swift ideological move toward the so-called "healthy migrant effect," according to which all migrants are young, strong, and healthy. This imagery, however, was - and still remains - evidently informed by a legacy of colonial ideology, ${ }^{4}$ one that envisions the foreigner as a superhuman endowed with biological superiority - and for this reason (probably) also naturally immune to the virus. Translated into practice, this belief has meant that a whole section of the population was entirely neglected - starting from the 230 new migrants who had landed on Italian shores in the meantime.

\section{Phase 2}

At the beginning of April, the migration issue returned to the political debate. On April 6, 2020, thirty-four migrants arrived in Italy by sea. The following day, an interministerial decree was issued by the minister of the interior Lamorgese together with the minister of infrastructure De Micheli, the minister of foreign affairs and international cooperation Di Maio, and the minister of health Speranza, ordering the immediate closure of the ports. ${ }^{5}$ As a follow-up, a civil protection decree was released on April 12, 2020, designating rescue ships as "hotspots" where quarantine for migrants (those at sea as well as those that had already landed) was to be carried out from now on. The management of the entire operation was entrusted to the Italian Red Cross. ${ }^{6}$ It was only after the resumption of landings (even though the numbers were not such as to justify the actions taken by the government") that the idea of the "spreader of the plague" resurfaced in popular discourse. The notion of the invulnerable migrant immediately took a back seat in favor of the stigmatized imagery of a foreigner carrier of diseases, which is obviously more pervasive because it is ancient. ${ }^{8}$ The health risk

4 The alleged physical superiority and resilience of foreigners was one of the main reasons adopted by slavers to justify the employment of African Americans in the cotton fields.

5 Decree no. 150, 7 April 2020, https://www.immigrazione.biz/upload/decreto_interministeriale_n_150_del_07-04-2020.pdf (26 Dec. 2020).

6 Decree of the Head of the Civil Protection Department no. 1287/2020, https://www.protezionecivile.gov.it/amministrazione-trasparente/provvedimenti/-/content-view/view/1250434 (26 Dec. 2020).

7 As Stege (2020) points out, the circular of April 7, 2020, was issued to prevent the Alan Kurdi from docking, even though all the people rescued tested negative, https://www.migrantes. it/wp-content/uploads/sites/50/2020/11/DirittodAsilo2020-23-11.pdf (26 Dec. 2020).

8 For example, see the headline in II Giornale of November 17, 1994, "Leprosy unloads in Sicily," very similar to the headline in Libero of June 25, 2020, "Importing the virus. 28 infected refugees unloaded in Sicily." 
posed by migrants who landed in our country has always been part of the national ideology, one that condensed military metaphors and stigmatization processes referring to "the contaminating invasion" (Sontag 1989: 38). Quite illustrational in this sense is minister Lamorgese's explanation of the establishment of quarantine ships. ${ }^{9}$

This decision was taken to guarantee the safety of our local communities, who were understandably worried as we are facing a pandemic [...] the quarantine ships are deployed to confine the migrants arriving on our territory for 14 days to protect the local communities. A call for tenders was made by civil protection. There will be costs, of course - maybe more than usual -, but there would have been costs regardless, even if the migrants had been relocated to a center on land. This, however, ensures more structure and, therefore, a greater sense of security. As I am not a politician, I am merely concerned with the safety of the country here..$^{10}$ (Emphasis mine)

\section{Phase 3}

The institutional narrative of quarantine ships as the most appropriate space for health checks and, consequently, for proper treatment imploded in the autumn with the death of two unaccompanied minors. Seventeen-year-old Abdellah Said died on September 14, 2020, in the local hospital in Catania, and shortly after, seventeen-year-old Abou Diakite passed away in Palermo on October 5.

These two young people did not "die because of COVID-19" but because of the medical complications that ensued after their prolonged imprisonment in Libya and subsequent journey at sea that had been overlooked as a result of the quarantine arrangements. It should be noted that only after these tragic events did the Ministry of the Interior allow minors to be quarantined on land. The narrative of ships as the safest solution - both for communities and for the people confined in them - was contradictory from the substantive view of protecting the right to health." In addition to the two cases mentioned above, it must be borne in mind that during this time, there had been self-harming ${ }^{12}$ and escape attempts reported on the ships,

9 Brant's fifteenthy-century story of the ship of fools recalls our contemporary account and parallels can be seen in the way the floating vessel becomes a distancing device that exempts the authority from its obligation of caring for the disadvantaged population.

10 https://www.interno.gov.it/it/ministro-lamorgese-sulle-navi-quarantena-sorveglianzasanitaria-dei-migranti (13 Jan. 2021).

11 In December 2020, a dossier was produced on the critical aspects of the quarantine vessels and at the same time a collection of signatures was started for their decommissioning, https:// www.meltingpot.org/IMG/pdf/criticita_del_sistema_navi-quarantena_per_persone_ migranti-_analisi_e_richieste.pdf (15 Jan. 2021).

12 On October 31, 2020, there are reports of people being detained in ships who have swallowed razor blades: https://tg24.sky.it/palermo/2020/10/31/migranti-sicilia (25 Jan. 2021). 
some leading to unfortunate outcomes,$^{13}$ without forgetting the studies that have established the highest risk of developing an epidemic in such confined spaces. ${ }^{14}$

Considering all these aspects, the symbolic function of the detention on ships with a bi-directional message is clear: one directed to citizens concerning the ability to pre-emptively remove people seeking international protection because they are perceived as dangerous according to the logic of the "plague spreader"; the other directed to migrants in the sense of deterring migration itself.

\section{Phase 4}

Between the end of 2020 and the beginning of the new year, all the attention shifted to the vaccination plan. At the time of writing (February 2021), the quarantine ships are still active and seemingly implementing the same practices as before. However, emergency measures that derogate from the right to liberty, and even before that, the right to health, should not be unlimited in time. The current phase shows a narrative trend similar to that of Phase 1 combined with that of Phase 3, namely a functional forgetfulness - accompanied by an exacerbation of the anxieties connected to the possible danger brought by the people disembarking. ${ }^{15}$ This functional forgetfulness on vaccines, however, deserves careful restitution, as it is fundamental to understanding the institutional logic in terms of prevention and safety, and at the same time the plasticity, the cogency of the gap between deserving and expendable.

On December 2, 2020, health minister Speranza illustrated the guidelines of the vaccination plan to the chambers, declaring that "the purchase of the vaccine is centralized and administered for free to all Italians. [...] The vaccine is a common good, a right that must be ensured for all people: women, men, regardless of their income and the area in which they live or work. No unequal treatment will be admissible in the vaccination campaign. ${ }^{\prime \prime 6}$ The minister's statement appeared to be totally in line with the double principle in Article 32 of the Constitution, which grants protection of the individual (without any discrimination) and the community. In this sense, it is safe to assume that the provisions regarding vaccination will concern all people residing in the national territory, regardless of citizenship or legal status (although

13 Bilal, a twenty-two-year-old Tunisian, died on May 6, 2020, when he jumped from the deck of the Moby Zazà to swim to Porto Empedocle.

14 The case of the Diamond Princess analyzed by the Centres for Disease Control and Prevention is emblematic, https://www.cdc.gov/mmwr/volumes/69/wr/mm6912e3.htm?s_ cid=mm6912e3_w (10 Feb. 2021).

15 This notion has returned to center stage in recent days in relation to the case of the Ocean Viking, which rescued 422 people. In fact, the media immediately highlighted the figure of eight positive cases on board. For information on this situation : https://www.agi.it/cronaca/ news/2021-02-07/migranti-augusta-ocean-viking-11312614/ (15 Feb. 2021).

16 http://www.salute.gov.it/portale/news/p3_2_1_1_1.jsp?lingua=italiano\&menu= notizie $\& p=$ dalministero\&id $=5202$ ( 18 Dec. 2020$)$. 
the minister spoke only of Italians). A few days after this message, the media started reporting that migrants might also be given access to the vaccine.

This fact in itself should not cause surprise: the inclusion of these people in the vaccination plan should be a given (if anything, what is surprising is the need to point it out). On December 6, 2020, the issue was discussed by the special commissioner for the COVID emergency, Arcuri, during an interview with Lucia Annunziata in a program on the state network. The following excerpt is significant in that special attention should be given to the words used by the journalist to talk about the phenomenon: ${ }^{17}$

- Annunziata: "Will foreigners living in Italy, whether Americans, Swedes or immigrants, be vaccinated?"

- Arcuri: "All the people who live in Italy will be vaccinated, of course, there are rule and hierarchies - some have been established already, and others are being reviewed currently as minister Speranza announced yesterday to the Parliament -, but everybody will have access according to the order of priorities that have been agreed upon."

- Annunziata: "So the migrants who are in ... in (um), let's say, somewhat uncertain situations and similar, will be the last ones being vaccinated?"

- Arcuri:"The vaccine will be free and not compulsory; this is important - free but not compulsory. We all understand that the higher the number of people living in Italy who will get vaccinated, the quicker we will achieve the so-called herd immunity, and soon we will find a way out of this dark tunnel we have been trapped in."

- Annunziata: "The thing about immigrants though, I'm sorry to insist, is very important. The immigrants who have ... Many immigrants who live here - they have residence permits; they have families, and they have rights."

- Arcuri: "And are therefore considered to have rights equal to those of Italian citizens." - Annunziata: "So, for example, we have a very migrant population - I mean migrants who move across regions ... because reception centers were canceled ... and those who are in the reception centers, will they be offered the vaccine? Considering it is a matter of national security."

- Arcuri "It would be very important and let me say no more, but it would be very important that all the people who cross our roads, and that they do not do it illegally, can be vaccinated. And, of course, it's important to say that they don't do it illegally." (Emphasis mine)

Avallone's ${ }^{18}$ concerns can therefore be confirmed: the risk is that the vaccination campaign will differentiate between nationals and non-nationals ab origine, leading to grave discrimination concerning the fundamental right to health, especially for

17 The interview can be found at https://vimeo.com/488038222 (18 Dec. 2020).

18 "Il vaccino non è per tutti" Avallone in Effimera, http://effimera.org/gli-immigrati-e-ildiscorso-del-potere-il-vaccino-non-e-per-tutti-di-gennaro-avallone/ (18 Dec. 2020). 
people labeled as "illegal immigrants" - with a considerable risk that people seeking international protection will also be included in this category.

Rocca, president of the International Federation of the Red Cross, pointed out on December 18 that migrants - regardless of their legal status - cannot be left behind in the vaccination campaign. ${ }^{19}$ The European Union has also spoken out on this, recommending that there should be no discrimination since the migrant population is already at greater risk of infection due to its limited access to health care. ${ }^{20}$

\section{QUARANTINE SHIPS: A QUESTIONABLE DEVICE}

If we consider Article 18 of the Montego Bay Convention, we learn that the prerogative to suspend the right of inoffensive passage can be implemented if the ship represents a danger, providing for the measure of quarantine. But the inter-ministerial circular of April 2020 is based on the opposite assumption, betraying the principles of international law: danger is in the country, on land, and not on the (more than controlled) ships. We are therefore witnessing an improper twisting of the content of the law, which attempts to conceal a systemic inefficiency. ${ }^{21}$ The argument for closing ports and creating quarantine ships is therefore based on comforting (following the old rhetoric) and confusing narratives: the land is no longer a safe place because of the virus, but shifting the blame - and thus the object of the restrictions - to the danger arriving by ship. By shifting the narrative toward the idea of a migrant as a "disease spreader" and leveraging the insecurities of the population sparked by the declaration of national emergency of January 31, 2020, the institutions fabricated a plausible justification for neglecting their obligations - thus leaving those people who had arrived on the Italian territory to fend for themselves in the middle of a global crisis.

The "closed ports" decree, issued without proof of the health risk posed by migrants rescued in the Mediterranean, represents the government's discrimination and negligence toward its international obligations. The declared danger of those ships was unfounded. Indeed, the only evidence in our possession shows that the poor conditions of detention and repatriation centers cause the spread

19 https://www.ansa.it/sito/notizie/mondo/europa/2020/12/17/covid-rocca-vaccino-per-imigranti-e-prioritario_7bff494c-939e-45a9-b65d-4b92ea103eb4.html (26 Dec. 2020).

20 Please refer to the IFRC report "Least Protected, Most Effected," https://media.ifrc.org/ ifrc/document/least-protected-affected-migrants-refugees-facing-extraordinary-riskscovid-19-pandemic/ and the dossier issued by the European Centre for Disease Prevention and Control at https://www.ecdc.europa.eu/en/publications-data/covid-19-guidanceprevention-control-migrant-refugee-centres (18 Feb. 2021).

21 It can be argued that by proposing quarantine ships as a solution to the problem the institution revealed and admitted its own inability to manage the land centers in respect of preventive health measures, thus allowing the deployment of stricter and harsher strategies. 
of the disease. ${ }^{22}$ Dr. Locatelli, president of the National Health Council and a member of the Scientific Technical Committee set up ad hoc to manage the health crisis, confirmed this point in an interview in the Corriere della Sera dated August 17, 2020, in which he stated: "Of the many asylum seekers in Italy, no more than 3-5\% tested positive, and some of them became infected in reception centers where it is more difficult to maintain adequate health measures."

Finally, one might consider Lamorgese's argument that quarantine ships are an efficient (albeit more expensive) solution to the problem of overcrowding in centers to guarantee the necessary distancing. There is, however, a further reflection that deserves to be made on the issue of distancing, as expressed by the minister in terms of greater security for the (Italian) community. If distancing is one of the ways of limiting contagion, at a symbolic level, it implies a sense of responsibility (and therefore closeness) toward the other. I am distancing myself from you for your sake and indirectly also for mine, thus recalling reciprocity. The strategy of delocalized distancing in the middle of the sea, on the other hand, implies a distance dictated by confinement beyond the shared territorial spatiality - canceling that sense of reciprocity and respect imposed on citizens - which can be summarized as follows: stay away for our sake. In this circumstance, the logic of differential physical distancing is proposed once again, that distancing implemented by the policies of externalization of borders; a creation of distance on a physical and symbolic level. Finally, if the pandemic has made it more difficult to monitor and assist the migrants, either detained or received, it has also made it almost impossible to know what was and still is happening inside the ships or centers. It justified rejecting not only unwanted migrants but also those who tried to keep a vigilant eye on inappropriate behavior. This rejection is similar to what happened with the criminalization of humanitarian ships in the Mediterranean, which were primarily opposed because they were troublesome witnesses.

Quarantine ships are thus a product of the unfortunate combination of the hotspot approach ${ }^{23}$ with the health crisis. As such, they risk becoming extra legem spaces - peculiar because they are disconnected from the land, completely deterritorialized. They are the perfect "camp-form" (Rahola 2006) since they are outside the territory, at sea. Although at the moment, the ships are in a roadstead close to

22 For critical issues in the current reception system, see ActionAid's report "Il sistema a un bivio" available at the following link: https://www.actionaid.it/app/uploads/2020/11/centri_dltalia_ sistema_a_un_bivio.pdf. For an analysis of detention conditions during COVID see: https:// cild.eu/wp-content/uploads/2020/07/Dossier_MigrantiCovid.pdf; https://www.law.ox.ac.uk/ research-subject-groups/centre-criminology/centreborder-criminologies/blog/2020/11/noone-looking-us; https://www.asgi.it/wp-content/uploads/2020/12/gue_migreurop.pdf (18 Feb. 2021).

23 The so-called hotspot approach stems from the implementation of the 2015 European Agenda. In this extra legem space the performative categorical logic - which is based on nationality - started to function ex ante, granting or denying the possibility to formulate the request for international protection. 
the mainland and therefore primarily within the territorial boundaries of Italian jurisdiction, all the uncertainties regarding who must fulfill the obligations of protection could create a dangerous vulnus.

Uncertainties regarding the responsibility of who should do what (The ship's flag state? The state providing safe port? The European Union as the reference entity for the management of the union's external borders?), a vacuum is created that may cause the freezing of rights. If the logic of the last few years has shown an increase of banned treatments by moving further and further south (Cuttitta 2006), the risk is that quarantine ships will be moved further and further away from the mainland. The quarantine ship apparatus - by enhancing exclusion policies and ensuring impunity through the circumvention of obligations - risks creating an alarming precedent for the conceptualization of "floating hotspots." This is how the health crisis has created the conditions for a not-so-new idea to finally take shape. ${ }^{24}$

\section{CONCLUDING REMARKS AND FUTURE SCENARIOS}

As we have seen in the previous pages, since the beginning of the health crisis, the treatment of migrants, and in particular of those seeking international protection, has been informed by negative assumptions derived from old stigmatizing rhetoric. But there has also been an acceleration, also in terms of intensity, of the state's ability to avoid its obligations to protect fundamental rights, first and foremost the right to health. Migrants, especially those without a valid residence permit or those who have just arrived in the country, suffer a doubly victimizing effect linked to the pandemic: they risk becoming infected more than others, and at the same time, they become more invisible than before, with a consequent limitation, erosion of their right to health.

It is precisely for these reasons that it is necessary to refer to the COVID pandemic - especially when considering non-citizens - in terms of a syndemic, ${ }^{25}$ since health conditions cannot be assessed merely by taking into account biomedical factors but must be understood within the broader context in which the person is socialized, both in environmental terms (housing and working conditions) and in legal terms (regularity or absence of residence permit) as well as structural terms (institutional discrimination). The pandemic has therefore provided a valid excuse for continuing to maintain an emergency securitarian approach or, rather, tightening it, thus moving

24 The idea of quarantine ships first came to Salvini in 2015 and then to Alfano in 2016. The solution of "floating hotspots" did not displease Europe at all, which was pleased with the proposal as the new device would make it more difficult for detained migrants to escape.

25 With respect to SARS-CoV-19 it would be more appropriate to talk about the old concept originated in medical anthropology of syndemic, as suggested by Lancet editor Richard Horton in an article of September 26, 2020, https://www.thelancet.com/journals/lancet/ article/PIIS0140-6736(20)32000-6/fulltext (19 Oct. 2020). 
away from the standards dictated by the legal systems (national, European, international), and consequently making it more difficult - if not impossible - to enforce fundamental rights. On the contrary, the measures taken to contain the health crisis appear more like a "pretext to reinforce borders and launch mass detention initiatives for asylum seekers. ${ }^{126}$ We are therefore witnessing a real spoliation of the disadvantage of applicants for international protection, where they appear expendable because they are not legitimate bearers of rights (Butler, Athanasiou 2013). If the aim of European policies seems to be to create and increase the distance between "us" and "them," the health measures adopted to contain the health emergency, as I have tried to demonstrate in my contribution, can provide excellent food for thought for reasoning on the lines of continuity between the before and after COVID-19.

If the measures adopted seem to simply re-propose the historically tested policies of externalization and refoulement, it is equally true that it would be necessary to take note of the further shift made in the direction of de-responsibility through the avoidance of legal obligations. We are, therefore, in the presence of a process of invisibility, both symbolic and physical, which is increasingly clever and capable of circumventing the duties of protection. It remains to be seen how long it will take for Italy - and more generally Europe - to acknowledge its own responsibility in this entire situation.

\section{REFERENCES}

Butler, Judith, Athanasiou, Athena (2013). Dispossession: The Performative in the Political. Cambridge: Polity Press.

Cuttitta, Paolo (2006). I confini d'Europa a Sud del Mediterraneo. Strumenti e incentivi per l'esternalizzazione dei controlli. Migrazioni, frontiere, diritti (eds. Paolo Cuttitta, Fulvio Vassallo Paleologo). Napoli: ESI, 13-40.

Geraci, Salvatore (2006). La sindrome di Salgari vent'anni dopo. Janus 21, 21-29.

Rahola, Federico (2006). La forma campo: Appunti per una genealogia dei luoghi di internamento contemporanei. DEP 5-6, 21.

Sontag, Susan (1989). L'aids e le sue metafore. Torino: Einaudi.

Stege, Ulrich (2020). Sbarchi e porti chiusi, tra Covid-19 e la "pavida" solidarietà in Unione Europea. II diritto d'asilo Report 2020 Costretti a fuggire ... ancora respinti, 37-57 https://www.migrantes.it/wp-content/uploads/sites/50/2020/11/DirittodAsilo2020-23-11.pdf (26 Dec. 2020).

26 The Balkan Route, Migrants without rights in the heart of Europe, June 2020, p. 41, https://www. balcanicaucaso.org/Media/Files/Dossier-La-rotta-balcanica.-I-migranti-senza-diritti-nelcuore-dell-Europa (18 Feb. 2021). 


\section{POVZETEK}

\section{STARA RETORIKA IN NOVA SREDSTVA: KARANTENSKE LADJE KOT SREDSTVO EKSTERNALIZACIJE Stefania SPADA}

Članek obravnava verbalni in institucionalni odnos Italije do migrantov, še zlasti prosilcev za mednarodno zaščito, med pandemijo. Na podlagi obnovitve različnih »vsebinskih faz« in posledičnih institucionalnih dejavnosti prikazuje, kako je zdravstvena kriza zaostrila in okrepila uveljavljena razmišljanja in prakse. S postopno etnografsko obnovo sprememb, ki so se odvijale od izbruha zdravstvene krize, dokumentira kontinuitete in prelome s prejšnjim obdobjem. Podatke iz etnografije vsakdanjega življenja, pridobljene z namenom boljšega razumevanja institucionalnega diskurza kakor tudi različnih vsebin, ki prevevajo splošni, vsakdanji diskurz, je avtorica primerjala s splošnejšimi razmišljanji o ukrepih nacionalne politike, usmerjenih v zajezitev migracijskih tokov. Čeprav izvedeni ukrepi izhajajo iz starih stereotipov in neprimernih starih upravljavskih metod, vsebujejo, kar zadeva njihov vpliv na materialne bivanjske razmere prosilcev za mednarodno zaščito, nekatere nove elemente. Pandemija je tako priročen izgovor za nadaljevanje sekuritarnega pristopa, značilnega za izredne razmere, to pa pomeni odmik od standardov, ki jih narekujejo pravni sistemi (nacionalni, evropski, mednarodni), posledično pa tudi oteženo, če že ne kar onemogočeno uresničevanje temeljnih človekovih pravic.

Ukrepi, ki naj bi pripomogli k zajezitvi zdravstvene krize, se zdijo bolj pretveza za okrepitev meja. Če je namen evropskih politik ustvarjanje oziroma povečevanje razdalj med »nami« in »njimi«, so zdravstveni ukrepi za ublažitev pandemije zelo prikladna tema za razmišljanje o kontinuiteti, ki se vleče od obdobja pred izbruhom pandemije do danes. Dejavnosti preteklega leta je mogoče razumeti kot nadaljnji korak v procesu eksternalizacije meja oziroma kot nekakšno deteritorializacijo, temelječo na uporabi karantenskih ladij, katerih namen je izogibanje državne politike zavezanosti mednarodnim in ustavnim obveznostim. V tem smislu lahko karantenske ladje razumemo kot uresničitev ne tako zelo nove zamisli, ki vodi Italijo še dlje po poti zanikanja temeljnih pravic prosilcev za mednarodno zaščito. Navsezadnje je pomembno tudi dvojno sporočilo simbolne funkcije zadrževanja migrantov na ladjah; prvo je namenjeno državljanom Italije in se nanaša na sposobnost države, da preventivno odstrani prosilce za mednarodno zaščito, ki jih ima v skladu z logiko »prenašalcev bolezni« za nevarne, drugo sporočilo pa je v smislu zatiranja migracij namenjeno migrantom samim. 